\title{
ПЕРСОНАЛІСТСЬКІ МОТИВИ У ТВОРЧОСТІ Т.Г. ШЕВЧЕНКА
}

\author{
Т.О. Дроздова
}

Питання про персоналістські мотиви у творчості Шевченка не зовсім нове у шевченкознавстві. Діаспорні дослідники Л. Плющ та В. Ящун торкалися деяких аспектів названої проблеми. Так, В. Ящун у статті «Шевченко у світлі персоналізму та індивідуалізму» $[15$, с. $413-$ 418], присвяченій в основному дослідженню проблеми свободи та відношенню Я-Ми у персоналістських та індивідуалістських конструкціях й розгляду творчості Шевченка на цьому тлі, дійшов висновку, що Шевченкове розуміння цього феномену наближене до персоналістського. Л.Плющ, аналізуючи діалогічність Шевченкової творчості, характеризуе їі, використовуючи термінологію М. Бубера, як «Я-Ти-відношення», при якому «Боже слово знімає тотальний абсурд, тотальну самотність людини, розгортається в душах в діалог межі людьми. I саме в џьому діалозі люди стають» [9, с.44]. Тобто, прямо не використовуючи означення «персоналістський», дослідник інтерпретує пошук слова у Шевченка саме у межах персоналістської комунікативної теорії. Н.Хамітов, розглядаючи концепції людини в українській культурі, дійшов висновку, що творчість Певченка репрезентуе суперечність між індивідуалізмом та персоналізмом, яка вирішується для поета в націоналізмі: «еремогу національного начала над індивідуалістичним - от що знаменуе герой Шевченка. Але саме в цьому хворобливому загостренні почуття національного, що кричить на весь світ і звертається до Бога, народжується людська гідність, що виходить за межі буденності. В граничному загостренні почуття національного для Т.Шевченка виявляється дійсна сердечність особистості в епоху несвободи нації» $[12$, с. $198-199]$. 
Але проблема персоналістської інтерпретації творчості поета, на наш погляд, вимагає уточнення ряду позицій, зокрема: наскільки правомірним, а якщо правомірним, то за яких умов, $є$ застосування поняття «персоналізм» стосовно митця, що не тільки ніколи його не використовував, а, напевне, й не знав, і у зв'язку з цим, яке значення сьогодні вкладається у поняття «персоналізм», в яких конкретно аспектах світогляду персоналістська установка виявляеться.

У сучасному філософському дискурсі семантика поняття «персоналізм» надзвичайно широка: це і певна філософія, і тон висловлювань про статус особистості, людські справи, сенс життя, цінності вибору i межі свободи. Його інтерпретують і як один напрямок, і як різноманіття течій, не дуже міцно пов'язаних між собою, і як комплекс антрополого-філософських тем, що вирішуються за допомогою різних методів філософствування. Не менше труднощів викликае і дефініція поняття «персоналіст», зокрема визначення того спільного принципу, що об'єднуе, хоча і з певними застереженнями та уточненнями, в рамках однієї філософії таких різних мислителів як Мунье, Марсель, Ройс, Лакруа, Доменек, Марітен, Бердяєв, Лосський, Шестов, Мерло-Понті, Бубер, Рікер.

Р. Авдєєва трактує це поняття так: «ерсоналізм - філософський напрямок, що розвиває ідею індивідуальної духовної субстанції як основи буття й був розповсюджений у кін. XIX - поч. XX ст. у Росіі, Германії, Франції, Америці» [1, с. 367-369]. Н. Хамітов розглядає його як «напрям філософії другої половини XX ст., що визнає особистість первинною творчою реальністю і вищою цінністю буття» $[13$, с. 476]. Проте, осмислення особистісного буття не було прерогативою лише ХХ ст. основні мотиви персоналістичної позиції розроблялися у філософській культурі, починаючи 3 періоду християнства, в основному в християнсько-містичних вченнях, де акщентуація робилася на особистісному переживанні взаємозв'язку людини зі світовим цілім. Тому нам видається доцільною спроба визначення персоналізму у двох аспектах, що їі робить Є.Гутов, визначаючи персоналізм і як комплекс релігійно-філософських течій, «що виступають за синтез релігійних, культурних та соціально-політичних концепцій на основі принципового значення самореалізації особистості у сучасному світі»; і в ширшому значенні - як «філософську позицію, що визнає особистість та особистісне існування основним предметом філософії й головною проблемою історії та культури» $[4$, с.515]. Підтримуючи загалом такий поділ значень поняття «персоналізм», Ю. Федорова [10, с. 232-233] пропонуе власне персоналістами вважати тих авторів, що декларують свою приналежність до 
цього напрямку, зокрема найбільш послідовного представника французького персоналізму Е. Мунье, який пропагував, хоча і без претензї на системність, персоналізм саме як окрему філософію, а не тільки філософську позицію. Якшо ж брати до уваги широке значення поняття персоналізм, то дослідниця пропонуе пов'язувати цю позицію 3 певною ціннісною, навіть ідеологічною установкою, яка зсередини визначае світоглядну перспективу. Близького погляду дотримуеться і Доброхотов [5, с. 316-321], що, розмірковуючи про цінності, називає персоналізмом будь-яку спробу вирватися 3 природного універсуму.

Крім того, як слушно наголошуе Є. Гутов, за широкого тлумачення термін персоналізм зазвичай пов'язуеться зі специфічним способом вираження «особистісної філософії, що за визначенням не може бути теоретичною, а базується на аутентичності досвіду особ́истого життя автора. Таким чином, «філософія як теоретична система поступається тут місцем філософствуванню як інтимно-екзистенційному переживанню, насиченій емоційній рефлексії над проблематичністю власної долі» $[4$, с. 515$]$.

I якщо поява персоналізму як особливої філософської течії датується XX ст., то персоналізм як філософська позиція виник набагато раніше. Українській філософії не довелося його сприймати чи запозичувати, оскільки персоналізм в цілому характерний для української ментальності, а відтак і для світоглядової спрямованості. Цей погляд обстоював О. Кульчицький, який, аналізуючи геополітичні, психологічні, історичні чинники, шо формували світоглядну настанову українців, а також філософську спадшину Г. Сковороди, П. Юркевича, творчість Т. Шевченка, І. Франка, стверджував, що в українській культурі основним об'єктом пізнання була гуманістична дійсність, що насичувало український «сцієнтизм етично-релігійними первнями», тому, на його думку, український тип характеру з розвинутим поняттям «серця» належить до кордоцентричного персоналізму, що втілюється у основоположні настанови до самопізнання, себетворення, самовдосконалення, причому себетворення, в основі якого лежить приеднання себе до вартостей, «проходить процесом приєднання вартостей до себе, процесом інтроцепції» $[7$, с. 44]. Ця точка зору, відповідно до якої «персоналізм постає найважливішим архетипом української культури» $[14$, с. 304], відтворюеться і в сучасному українському філософському дискурсі (I. Бичко [2], Н. Хамітов [14], О. Гук [3]). На наш погляд, термін «персоналізм» можна застосувати до творчості Шевченка саме як світоглядну позицію, оскільки художня творчість останнього $є$ виразною рефлексією над долею людини, а проблеми, що постають перед його 
людиною - це проблеми, що виростають із його власного життя, виступаючи для нього чинником його особистісного вибору.

Свого часу, спробувавши з'ясувати, які філософські теорії близькі поетові та виокремити цілісний філософський світогляд Шевченка, подібний висновок зробив І. Фізер, визначивши філософсько-поетичні роздуми поета не як філософію (теоретичну систему): «У літературній спадшині Шевченка немає філософії як систематичного дослідження метафізичних, історіософічних, етичних та естетичних проблем» $[11$, с.51], - а як філо-софію - наявність у творчості Шевченка філософічних рис, тем та понять 3 виразно філософічним навантаженням, що виступають у «сув'язі з іншими» (любовними, побутовими, історичними, політичними, релігійними) темами та виконують функцію «або семантичного акомпаньямента, або ідейної рами тексту» $[11$, с.52].

Узагальнюючи, основними ознаками наявності саме персоналістичної позиції можна вважати:

- таке розуміння особистості, за яким вона не може бути зведена лише до природи, навіть своєї власної, і прагнення осмислити цей факт;

- персоналізація буття, що виражається у відмові від орієнтації на такі метафізичні положення, які не здатні укорінити особистість у світі;

- спрямованість на пошуки підходів до того, як знайти Бога экзистенціально, як опанувати здатність розкрити Його існування в людині і світі.

Наслідком такої позиції е орієнтація на соціальність в уявленнях про особистість, прагнення до трансценденції з одночасною вимогою долучення людини до реального світу, тоб́то визнання незалежної від людської свідомості дійсності, прагнення подолати метафізичну абстрактність, рух до конкретності, думки про єдність всього людства, що опосередковують усю особистісну своєрідність. Саме такими мотивами насичена і творчість Шевченка. Людина «долучена», відкрита світові, така, що вболівае за світ, спасає світ, - це ідеал людини для Шевченка (мати Алкіда у «Неофітах», Марія, Юродивий в однойменних поемах).

Творчість Шевченка, як це не раз відзначали, наскрізь антропоцентрична. Але персоналізм за широкого тлумачення терміну не тотожний ні антропологізму, ні антропоцентризму. Справді, для поета 
немае нічого важливішого, дорожчого за людину, хоча, може, водночас нема нічого страшнішого за людину. Людина, особистість, їі безмежна глибина та невичерпні потенційні можливості, її співзвучність та містичне поєднання зі світовим буттям та безоднею духовної реальності були постійною темою медитапій та поетико-філософічних роздумів Шевченка. Послідовно і терпляче, як ніхто до нього в українській культурі, поет розкривае темний бік людини, сили руйнування, егоїзм, аморалізм, що приховані у глибинах їі душі («Варнак», «Титарівна», «Гайдамаки»). Але не можна не побачити, що розкриває Певченко і світлі порухи людської душі, діалектику добра у ній. Антропоцентризм митця персоналістичний та етичний, це означае, що саме сприйняття людини у Певченка пронизане етичною категорією, він не просто описує боротьбу добра і зла в людині, він шукає їі. I справжне у людині, сенс іiі існування для поета - в етичному житті тут і тепер. Шевченківська людина, що втілюеться у різних характерах, які проте виявляють спільну духовну структуру, на думку Д. Козія, вирізняеться «триваловисокою наснагою почуття», «Здатністю до подвигу і вольовою спрямованістю на здійснювання етичних цінностей» [7, с. 4]. Самовідданість і самозречення його Наймички постае не через пасивну підкореність невблаганній долі, не через почуття провини перед своїм родом і Богом, а від «повноти любові, яка освячуе матір» $[7$, с. $5-6]$.

Безжально і безкомпромісно розкривае поет фатальну розщепленість духу людського, головне в людині, за Шевченком, в тому, що вона істота етична, що людина завжди стоїть перед дилемою добра і зла, від якої ніде сховатися: якщо людина не йде шляхом добра, то обов'язково опиняється на шляху зла. Онтологія людини у Шевченка визначається її прагненням до свободи. Подібно до Достоєвського він стверджуе, що свобода - найдорожче для людини, але водночас вона виявляеться і тягарем, нести який вкрай важко. Шлях до добра не визначається самою лише свободою, він ірраціональний у тому сенсі, що не визначається розумом, а визначається волею та силою духу. Таку силу духу демонструє Відьма своєю здатністю до духовного оновлення, кинута життєвими негараздами на саме дно, вона повертається до людей, щоб творити добро: «Відьма, життя якої кричить про владу зла, діє з мотивів, які приховуються в їі глибинній свідомості і які підказують ій, що добро треба творити, не дивлячись на те, чи зло переважає в світі, чи ні. Вона читає у своєму серці, що світ є таким, яким його люди творять, яким його хочуть мати в своїй добрій вірі або в своєму засліпленні» [7, с. 6-7].

У розумінні свободи Шевченко найбільш близький до персоналізму, 
оскільки свобода людини у поета виявляеться у любові до ближнього. Якщо у екзистенціалізмі Сартра інші люди є перепоною для здійснення особистісної свободи, центром всесвіту він вважае індивіда, то для Шевченка свобода виявляеться у ставленні до інших, головним для нього $\boldsymbol{e}$ людська спільнота з Богом у центрі. Тому і свобода, відірвана від живих порухів любові, може призвести до руйнації і смерті. Так відбувається тому, що, на переконання поета, людина не може відійти від добра, а коли таке трапляеться, то вона неминуче опиняеться у прірві страшної болісної й нестерпної душевної хвороби. Ті персонажі його творів, що чинять зло, страждають через те, що задавили у собі відчуття добра (тобто Бога), відмовилися від можливості трансценденції і через це залишилися сам на сам із собою. Свобода, коли вона залишає нас наодинці з собою, відкриває у нашій душі лише хаос, оголюе темні й низькі порухи, перетворюе на рабів пристрасті. Це означае, що людина створена етичною істотою і не може припинити бути нею. Болісно і пристрасно говорить Шевченко і про те, що злочин зовсім не означае природної аморальності людини, а навпаки свідчить про те, що відходячи від добра людина втрачає те, без чого її життя неможливе. Проблематика свободи у людині - одна 3 домінант Певченкового персоналізму: і до добра, і до зла людина у поета іде сама, з власної волі. У порухові свободи для Шевченка присутня діалектика зла, але так само присутня й діалектика добра, а страждання, через які проходять герої його творів можуть свідчити про те, що, можливо, саме через страждання (гріх) набуває потенції ця діалектика добра. Буття для поета добре («рай та й годі»), світло і правда уже $\boldsymbol{e}$ у цьому світі, але вони залишаються непоміченими людьми, Христос для того й приходив у цей світ, аби людство зрозуміло, що його земна природа i його дух можуть набути рис Божественного добра, що це природно і можливо, а не лише ідеал та мрія. Ця діалектика природного і можливого добра передбачає для Шевченка звернення людини до Бога. Так, герой поеми та повісті «Варнак» тільки тимчасово піддається ненависті, яка постае як вислід кривди від панів для всіх простих людей. Поступово Варнак усвідомлює ту безвихідь, в яку загнало його зло у відповідь. Відбувається моральний злам і переоцінка вартостей життя, причому розбиту душу Варнака рятує саме звернення до Бога, момент духовного відродження злодія Шевченко детермінує саме Божим осяянням від споглядання «Святого Києва».

Як вважає Шевченко, людина живе по-справжньому лише тоді, коли вона осяяна Божою благодаттю, прагне реалізувати вічне у перехідному. Причому усвідомлення прірви між перехідним та вічним, 
що розкривае істину про ницість земних справ як індивідуальних, так і суспільних, відкриває одночасно істину про величезну відстань між людиною та Богом, що породжуе хвилі сумніву та страху. I лише Божа благодать може допомогти подолати прірву. Саме вона є істинним рушіем внутрішньої діалектики віри: постійного хитання між сумнівом та переконанням. Але устремління до Бога не тотожне для поета покорі та смиренню, яке виправдовуе підкорення одніеї людини іншою. Він пристрасно виступае проти християнської суспільності та православної церкви, що просякли міщанством. Так само, як пізніше Мунье, що чинником «пасивного консерватизму» та «м'якої безпорадності» людей вважав «рабські нахили» [16, с. 55], Шевченко не сприймае середовища, у якому пануе рабська схильність до залежності і безвідповідальності, застерігає: «ми не раби Його, ми люде», Господь для Шевченка - це можливість, підтримка, путь, що спрямовує людину до самоздійснення, реалізації найважливішого для поета принципу діяльної любові до ближнього, саме до Бога звертається Шевченко 3 пристрасним проханням: «не дай гнилою колодою по світу валятись, а дай жити, серцем жити, і людей любити».

Отже, людина у творчості Шевченка демонструє характерний для персоналістського світобачення приклад героїчного життєствердження, яке виявляється у здатності переборювати зло [6, с. 37-51], [7, с. 14], морально відроджуватися після падіння, вірити у людину, їі потенційні можливості та стверджувати вищий принцип Буття.

\section{1 Бібліографія}

[1] Авдеева Л. Персонализм // Русская философия: Словарь / Под общ. ред. М. Маслина.- М., 1999. - С. 367-369.

[2] Бичко I. Український національний характер: персоналістський підхід // Філософсько-антропологічні читання'96. Випуск 2. - К., 1996. - C. $21-27$.

[3] Гук О. Проблема цілісності людського буття у філософії О. Кульчицького // Практична філософія. - 2005. - N2. - С. 44 50 .

[4] Гутов E. Персонализм // Современный философский словарь / Под общ. ред. В. Кемерова. - М., 2004.- С. 515-516. 
[5] Доброхотов Л. Вопросы и ответы об аксиологии В.К. Шохина // Альфа и Омега. Ученые записки Общества по распространению Святого Писания в России. Вып. 3.- М., 1998. - С. 316-321.

[6] Козій Д. Шевченківське життествердження // Сучасність.1975. - o 3. - С. 37-51.

[7] Козій Д. Шевченківська людина // Сучасність. - 1974. - №3. C. $3-15$.

[8] Кульиицький O. Український персоналізм. Філософська етнопсихологічна синтеза. - Мюнхен-Париж, 1985.

[9] Плющ Л. Я-Ти-слово Т.Шевченка // Сучасність.-1984.№3. - C. $30-55$.

[10] Федорова Ю. Мотивы персонализма в отечественной философии XIX-XX веков: истоки и перспективы // Философский век. Альманах. Вып. 10. Философия как судьба: Российский философ как Социокультурный тип. - СПб., 1999. - С. 231-244.

[11] Фізер I. Філософія чи філо-софія Тараса Шевченка // Світи Тараса Шевченка: Зб. статей до 175-річчя 3 дня народження поета. Нью-Йорк, 1991. - С. 47-54.

[12] Хамітов Н., Гармаш Л., Крилова С. Історія філософії. Проблема людини та її меж. - К., 2000.

[13] Хамітов Н. Персоналізм // Філософський енциклопедичний словник. - К., 2002. - С. 476-477.

[14] Хамітов Н. Феномен етноантропології // Філософія. Світ людини. Курс лекцій. - К., 1997. - С. 298-310.

[15] Ящун В. Тарас Шевченко в світлі індивідуалізму та персоналізму // Визвольний шлях. - 1987. - o 4. - С. 413-418.

[16] Mounier E. Qu'est-ce que le personnalisme? - P., 1946. 